\title{
Growth, Metabolic and Physiological Response of Juvenile Cheraxquadricarinatus Fed Different Available Nutritional Substrates
}

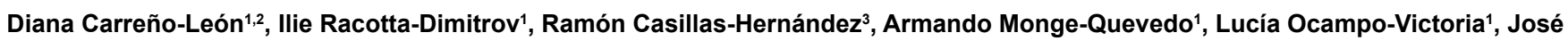
Naranjo-Páramo ${ }^{1}$ and HumbertoVillarreal ${ }^{1 *}$

${ }^{1}$ Centro de InvestigacionesBiológicasdelNoroeste (CIBNOR), Mar Bermejo 195, La Paz, B.C.S. 23090, México

${ }^{2}$ Doctoral Candidate at InstitutoTecnológico de Sonora, México

3Instituto Tecnológico de Sonora. 5 de Febrero 818 Sur, Centro, 85000 Ciudad Obregón, Sonora, México

\begin{abstract}
There are many factors in intensive culture conditions which vary the physiological response of organisms in culture affecting performance such as growth, metabolic levels in blood, respiratory metabolism and the inflection point of dissolved oxygen concentration. The study was conducted under high density culture conditions with multitrophic systems. Results show that the species can tolerate intensive culture conditions without affecting their growth and survival and has the ability to leverage multiple food sources. This work also shows that Cheraxquadricarinatus has the ability to maintain a low routine metabolic rate, is highly tolerant to limited dissolved oxygen conditions and thus uses energy efficiently. The metabolic rate in juvenile $C$. quadricarinatus was $0.07 \pm 0.003 \mathrm{mg} \mathrm{O} / \mathrm{g} / \mathrm{h}$ while the critical level of oxygenconcentration, when the organism passes from regulator to conformer is $0.483 \pm 0.002 \mathrm{mg}$ $\mathrm{O}_{2} / \mathrm{L}$. This is significantly lower than previously reported for cultured decapod species.
\end{abstract}

Keywords: Crayfish; C. quadricarinatus; Metabolism; Oxygen; Glucose; Lactate

\section{Introduction}

Cheraxquadricarinatus is an omnivorous species originated in Australia, with ideal characteristics for commercial culture, such as growth rate [1], that allows for harvest of commercial size organisms in 6-8 months [2]. It was introduced in Mexico in the 90's [3] and is mainly cultured in the northeast region. Research studies have been conducted with the species, such as nutrition [4-6], reproduction and embryonic development [7-10], growth [11] and technology development for commercial culture [12]. Nevertheless, to optimize development during culture it is necessary to know and explore the limits of the physiological response of the organism under varying conditions. In particular, nutritional substrates have shown to produce a different response in terms of growth, and physiological response [13-16]. The metabolic rate is an index frequently used in aquaculture [17], where oxygen consumption determinations contribute to define energy use patterns and serves to determine stress related to environmental conditions [18] and the inflection point of dissolved oxygen concentration where the organisms switches from metabolic regulator to conformer [19]. Several authors [17-19,20-25] have reported results on the effect of environmental conditions, such as salinity and temperature, in the metabolic response of crustaceans. On the other hand, changes in hemolymph metabolites have been reported by several authors as a tool to define the physiological state of the organism, in relation to variations in temperature, salinity and oxygen concentration [2630], reproductive performance [7,31-33], nutritional state [34-38], handling-stress [39,40], and disease infection [41]. In its natural habitat, C. quadricarinatus has been found in extreme temperatures and low oxygen concentrations $[42,43]$, and has been reported to be very tolerant to environmental variations $[1,2,44]$. Nevertheless, the limits have not been established, the physiological response has not been defined, and the impact on production in culture conditions has not been measured [18]. This is of particular importance, as the current trends for aquaculture point towards intensification and the use of multitrophic systems [12,45-47]. Systems, using photoautotrophic or heterotrophic strategies $[46,48-50]$ are based on the specific control of microalgae, plankton and bacterial populations to reduce undesirable metabolites, improve the use of supplemental nutrients and maximize system efficiency. The use of probiotics such as Bacillus spp. [46,51-53], Saccharomycescerevisiae [54], Lactobacillus $[55,56]$ has been reported to improve water quality, improve growth rates on shrimp [57-59], tilapia [54,60,61], marine fish larvae [62], oyster [63] and reduce the impact of pathogens $[46,53,64-66]$.This work presents the growth, metabolic and physiological response of juvenile C.quadricarinatus grown in systems with varying available nutrient substrates.

\section{Materials and Methods}

\section{Experimental organisms and acclimation}

Cheraxquadricarinatus juveniles $(1.5 \pm 0.3 \mathrm{~g})$ were obtained from the experimental reproduction ponds at the Centro de Investigaciones Biológicas del Noroeste (CIBNOR) and placed in 1,000 1 fiberglass tanks $(1.00 \mathrm{~m}$ wide $\times 2.00 \mathrm{~m}$ long $\times 0.50 \mathrm{~m}$ deep $)$ with filtered freshwater at $28 \pm 1^{\circ} \mathrm{C}$ and constant aeration for acclimation.

\section{Culture conditions}

An experimental system with fiberglass tanks measuring $0.26 \mathrm{~m}^{2}(0.38 \times 0.69 \mathrm{~m})$ with $60 \mathrm{l}$ was used. Twenty five juvenile $C$. quadricarinatuswere randomly selected and placed in each unit at a density of 96 juveniles $/ \mathrm{m}^{2}$. The experimental units had filtered water at $28.0 \pm 0.5^{\circ} \mathrm{C}$; with oxygen saturation maintained at $7.37 \pm 0.38$

*Corresponding author: Humberto Villarreal, Centro de InvestigacionesBiológicas del Noroeste (CIBNOR), Mar Bermejo 195, La Paz, B.C.S. 23090, México, Tel: +52-612-123-8484-3752; E-mail: humberto04@cibnor.mx

Received October 14, 2013; Accepted January 27, 2014; Published January 31 2014

Citation: Carreño-León D, Racotta-Dimitrov I, Casillas-Hernández R, MongeQuevedo A, Ocampo-Victoria L, et al. (2014) Growth, Metabolic and Physiological Response of Juvenile Cheraxquadricarinatus Fed Different Available Nutritional Substrates. J Aquac Res Development 5: 220 doi:10.4172/2155-9546.1000220

Copyright: (c) 2014 Carreño-León D, et al. This is an open-access article distributed under the terms of the Creative Commons Attribution License, which permits unrestricted use, distribution, and reproduction in any medium, provided the original author and source are credited. 
Citation: Carreño-León D, Racotta-Dimitrov I, Casillas-Hernández R, Monge-Quevedo A, Ocampo-Victoria L, et al. (2014) Growth, Metabolic and Physiological Response of Juvenile Cheraxquadricarinatus Fed Different Available Nutritional Substrates. J Aquac Res Development 5: 220 doi:10.4172/2155-9546.1000220

Page 2 of 7

$\mathrm{mg} \mathrm{O}_{2} / 1$ and a light cycle adjusted to 14 hours per day. Water quality (temperature, $\mathrm{pH}$,oxygen saturation) was recorded daily. Water exchange of $20 \%$ was used to collect and eliminate feces and uneaten feed. Nylon mesh hiding places $\left(1 \mathrm{~m}^{2}\right)$ were introduced in each tank to avoid cannibalism [43]. Growth and survival were evaluated every 15 days for 60 days.

\section{Experimental treatments}

Two treatments and one control group were tested with four replicates each: (1) Natural productivity from grow out ponds at CIBNOR. Daily supply of unfiltered water from culture ponds to the experimental units, to simulate primary productivity conditions during the trial; and (2) A commercial probiotic (Ecoterra $\left.{ }^{\circledR}\right)$, which was prepared 24 hours prior to use, following the manufacturers recommendations. This commercial probiotic is composed of B.licheniformis, B.subtilis, Nitrobacter,Nitrosomonas, Rizobium, S.cereviciae and T.oxidans, which were identified through microscope and counted using a hemacytometer to determine the concentration of the prepared inoculum. Cell concentration in every experimental tank was determined after routine water exchange and probiotics were added to reach a total of 200,000 cells/liter. The control group (Filtered water) had units with filtered (5 micron) and UV treated freshwater. All the experimental units were fed a commercial shrimp pellet $(35 \%$ crude protein) twice a day, for a total of $2 \%$ of the crayfish biomass [67]. Overall, the probiotic mix had a mean biochemical composition of $88.87 \mathrm{mg} / \mathrm{L}$ proteins, $33.08 \mathrm{mg} / \mathrm{L}$ lipids and $36.65 \mathrm{mg} / \mathrm{L}$ carbohydrates. The mean biochemical composition of primary productivity was of $9.06 \mathrm{mg} / \mathrm{L}$ proteins, $5.84 \mathrm{mg} / \mathrm{L}$ lipids and $4.34 \mathrm{mg} / \mathrm{L}$ carbohydrates.

\section{Growth trial}

Juvenile performance was evaluated as follows:

a) Specific growth rate (average growth per day),SGR=( $\ln W_{f}-$ $\left.\ln \mathrm{W}_{\mathrm{i}}\right) / \mathrm{t} \times 100$,

where (days).

$\mathrm{W}_{\mathrm{f}}$ represents final weight $(\mathrm{g}), \mathrm{W}_{\mathrm{i}}$ is the initial weight and $\mathrm{t}$ is time

b) Apparent food conversion rate, FCR = Food fed (g)/Weight gain $(\mathrm{g})$

c) Survival \%, $\mathrm{S}=$ (Final number of juveniles/ Initial number of juveniles $) \times 100$

\section{Biochemical analyses}

At the end of the experiment, 20 juveniles were randomly selected from each treatment and hemolymph was extracted using 5\% potassium oxalate as anticoagulant. Ten $\mu \mathrm{l}$ were used for hemocyanin analysis [68]. The rest was centrifuged at $3600 \mathrm{rpm}$ and $10^{\circ} \mathrm{C}$ for 10 minutes to obtain plasma [69], to test for glucose (GOD PAP GL2623, Randox Method), lactate (LC2389 PAP Randox method), protein [70] and total lipids [71]. All the analyses were done using micro plates [69]. Additionally also performed these analyzes in hemolymph biochemical to a juveniles group from culture ponds which were not subject to the multi-trophic culture system to obtain baseline values.

\section{Metabolic rate and the inflection point of dissolved oxygen concentration (IP)}

The metabolic rate was determined using a closed respirometer
[22] for 20 randomly selected juveniles per treatment. After the experimental culture period, the organisms were starved for 24 hours to insure their digestive system was emptied $[20,72]$. The juveniles were placed individually in respirometers one hour before the evaluation, allowing the crayfish to acclimate. Temperature and aeration were maintained constant during this time. The metabolic rate was individually determined in water saturated with oxygen at $28 \pm 0.5^{\circ} \mathrm{C}$. A control blank (a respirometer without an experimental organism) was used for every 10 respirometers with experimental organisms. Oxygen saturation was recorded at the beginning of the trial and every 15 minutes for 1 hour, using a PreSens Precision System ${ }^{\circledR}$ (Regensburg, Germany) with a fiber optic oxygen sensor. The metabolic rate (MR) was determined using the equation:

\section{d) $M R=D O / W / t$,}

where $D O$ represents milligrams of oxygen, $\mathrm{W}$ is weight $(\mathrm{g})$ and $t$ is time (hours). After the evaluation, the organisms were weighted $(0.01 \mathrm{~g})$ using a digital balance (Sartorius Portable PT600, precision $\pm 0.01 \mathrm{~g}$, Gottingen, Germany), and a hemolymph sample taken for biochemical analyses, as described above. The inflection point of dissolved oxygen concentration (IP) was determined in independent trials using the respirometer described above. Oxygen saturation was recorded every 15 minutes until the variation between 3 recordings was not significant. After the evaluation, the organisms were weighted and a hemolymph sample taken for biochemical analyses, as described above. The inflection point of dissolved oxygen concentration (IP) was established as the intersection of best-fitlinear regressions above and below the inflexion point where the organism passes from regulator to conformer $[22,73]$.

\section{Statistical analyses}

Normality and homoscedasticity of data was tested before a oneway ANOVA test was used [74] to compare treatments. A-posteriori tests were used to determine statistical differences between treatments [75], using STATISTICA $6^{\circledR}$.

\section{Results}

\section{Overall performance}

Results did not show statistical differences between treatments in terms of final weight, survival and FCR (Table 1), with acceptable growth rates for all treatments (mean $=2.1 \pm 0.1 \mathrm{~g} /$ week). Similarly, no differences were observed for survival that was around $70 \%$.

\section{Biochemical analyses}

Total lipids in hemolymph were similar for all treatments (Table 2) with juveniles from the probiotic treatment showing the highest mean value. After the metabolic evaluation in the respirometer, the lipid level for this treatment had the lowest mean value. Table 2 also shows that there were no significant differences in total proteins, hemocyanin and the proportion of hemocyanin/protein. Significantly higher levels of hemolymph glucose $(\mathrm{P}<0.05)$ were observed for the treatment with added probiotics $(0.34 \pm 0.08 \mathrm{mg} / \mathrm{ml})$, compared to all other treatements $(0.1$ and $0.15 \mathrm{mg} / \mathrm{ml})$ (Figure 1a). A similar pattern was found for total lactate, where all treatments showed higher values than the baseline levels $(0.04 \pm 0.02 \mathrm{mg} / \mathrm{ml})$, especially the treatment with added probiotic $(1.86 \pm 0.59 \mathrm{mg} / \mathrm{ml})$ (Figure $1 \mathrm{~b}$ ). Limiting oxygen concentration during the metabolic trials in the respirometer produced a significant reduction in glucose and lactate levels in juveniles from the probiotic treatment (Figure 2). Conversely, glucose was highest 
Citation: Carreño-León D, Racotta-Dimitrov I, Casillas-Hernández R, Monge-Quevedo A, Ocampo-Victoria L, et al. (2014) Growth, Metabolic and Physiological Response of Juvenile Cheraxquadricarinatus Fed Different Available Nutritional Substrates. J Aquac Res Development 5: 220 doi:10.4172/2155-9546.1000220

Page 3 of 7

\begin{tabular}{|c|c|c|c|c|}
\hline Culture condition & Initial weight $\mathbf{( g )}$ & Final weight (g) & SGR (\%/day) & \\
\hline & & & \\
\hline Filtered Water & $1.47 \pm 0.11$ & $5.57 \pm 1.91$ & $2.2 \pm 0.2$ \\
\hline Primary productivity & $1.49 \pm 0.07$ & $5.26 \pm 1.89$ & $0.5 \pm 0.10$ \\
\hline Probiotics & $1.54 \pm 0.04$ & $5.45 \pm 1.75$ & $2.1 \pm 0.1$ \\
\hline
\end{tabular}

Table 1: Mean values \pm standard deviation of initial and final weight, specific growth rate (SGR) and feed conversion rate (FCR) of juvenile Cheraxquadricarinatus for different nutritional substrates. (ANOVA $p>0.05, n=$ number of organisms per treatment).

\begin{tabular}{|c|c|c|c|c|c|}
\hline Juvenilecondition & Culture condition & Total Proteins & Total Lipids & Hemocyanin & Ratio \\
\hline & & $(\mathrm{mg} / \mathrm{ml})$ & $(\mathrm{mg} / \mathrm{ml})$ & $(\mathrm{mmol} / \mathrm{L})$ & $\mathrm{HC} / \mathrm{TP}(\%)$ \\
\hline Before & Baseline values* & $443.46 \pm 5.4$ & $2.30 \pm 0.60$ & $2.71 \pm 0.61$ & $39.0 \pm 3.15$ \\
\hline standard & Filtered Water & & & & \\
\hline metabolic & (Control group) & $483.27 \pm 84.2$ & $2.46 \pm 0.86$ & $3.14 \pm 0.82$ & $40.1 \pm 5.39$ \\
\hline rate & Primary & & & & \\
\hline \multirow[t]{2}{*}{ evaluation } & productivity & $498.42 \pm 79.8$ & $2.60 \pm 1.46$ & $3.18 \pm 0.82$ & $38.9 \pm 6.38$ \\
\hline & Probiotics. & $488.53 \pm 73.5$ & $3.48 \pm 0.87$ & $3.55 \pm 0.77$ & $43.4 \pm 4.91$ \\
\hline Post & Filtered Water & & & & \\
\hline metabolic & (Control group) & $525,50 \pm 44,1$ & $3,05 \pm 1,36$ & $2,96 \pm 0,34$ & $34,9 \pm 8,90$ \\
\hline \multirow[t]{3}{*}{ evaluation } & Primary & & & & \\
\hline & productivity & $494.58 \pm 44.6$ & $3.10 \pm 1.50$ & $3.10 \pm 1.50$ & $54.3 \pm 10.4$ \\
\hline & Probiotics. & $481.78 \pm 37.0$ & $1.90 \pm 0.62$ & $2.64 \pm 0.82$ & $37.1 \pm 10.6$ \\
\hline
\end{tabular}

Table 2: Mean values \pm standard deviation of the concentration of total protein (PT), total lipids and hemocyanin (HC) in the hemolymph of juvenile Cheraxquadricarinatus for different growing conditions, before standard metabolic rate evaluation and post metabolic evaluation. The ratios between hemocyanin andtotal proteins are presented as percentage \pm standard deviation, $n=20$. (ANOVA $p>0.05, n=$ number of organisms used for biochemical analysis). ${ }^{*}$ Juveniles from culture ponds not subject to the multitrophic culture system.

for the natural productivity treatment. In a general way, glucose and lactate levels increased after the metabolic trials, when compared with analysis made from random samples at the end of the growth trial in the treatments with filtered water and natural productivity.

\section{Metabolic rate and the inflection point of dissolved oxygen concentration (IP)}

There were no significant differences in terms of standard metabolic rate (Figure $3 \mathrm{a}$ ), though natural productivity and probiotic treatments showed a slightly higher mean. In terms of the inflection point of dissolved oxygen concentration (IP) the values shown are significantly lower than previously reported data, but there were no significant differences between treatments (Figure 3b).

\section{Discussion}

The experimental treatments did not have an effect on production efficiency of juvenile Cheraxquadricarinatus, in terms of growth and survival. Juvenile growth reported in this work compares favorably

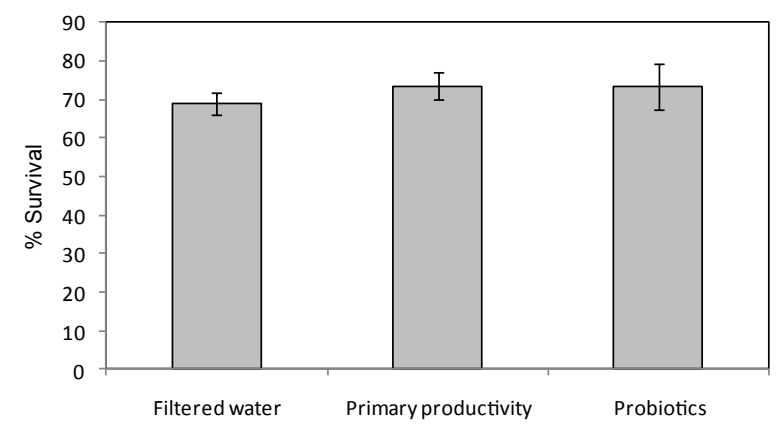

Figure 1: Survival (\%; mean \pm s.d.) during intensive culture of juvenile $C$ quadricarinatus for different treatments: (1) Filtered fresh water system, (2) Addition of primary productivity and (3) Addition of probiotics. (ANOVA $p>0.05$ ).

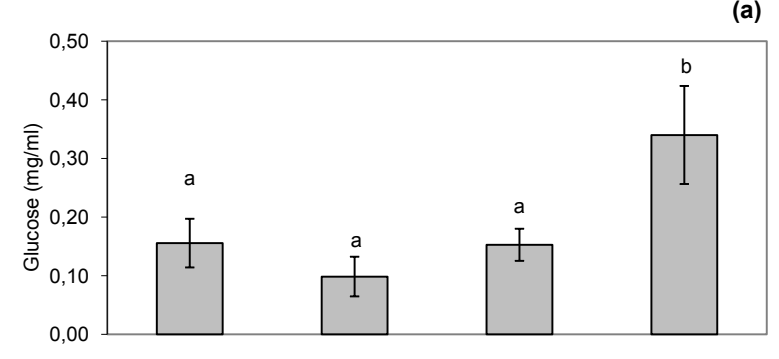

(b)

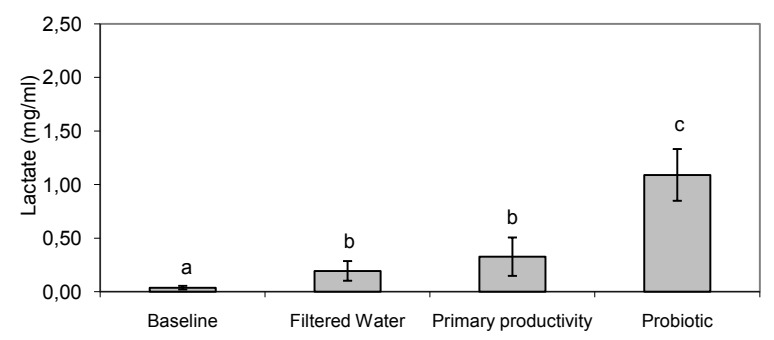

Figure 2: Concentration of glucose (a) and lactate (b) in the hemolymph of juvenile Cherax quadricarinatus for different nutritional substrates before standard metabolic rate evaluation. The letters denote significant differences between treatments. (ANOVA $P<0.05$ ).

with previous reports $[67,76]$. The meanfood conversion rates $(0.4 \pm$ 0.02 ) were significantly lower than those reported for this and other decapods. Some research $[4,43,77]$ have reported experimental and commercial juvenile C. quadricarinatus FCR's ranging from 0.8 a 1.21. This indicates that the species is energetically efficient, which is consistent with an omnivore with ample capacity to use several food sources for good performance [78], having the ability to use a diverse range of nutrient substrates [79], such as the multitrophic systems 
Citation: Carreño-León D, Racotta-Dimitrov I, Casillas-Hernández R, Monge-Quevedo A, Ocampo-Victoria L, et al. (2014) Growth, Metabolic and Physiological Response of Juvenile Cheraxquadricarinatus Fed Different Available Nutritional Substrates. J Aquac Res Development 5: 220 doi:10.4172/2155-9546.1000220

Page 4 of 7

that usually develops in outdoor culture systems [43]. It has been reported that freshwater crayfish increase their total consumption intake when offered a variety of feeds [78], increasing the total energy available. Also, reports indicate that the addition of diverse natural nutrient sources can improve the survival of cultured organisms [46,47]. In our trial, survival was slightly higher for treatments with added natural productivity or probiotics, and better than the reports by other authors $[11,76]$.Variations in specific biochemical parameters in the haemolymph contribute to elucidate both the condition of the organism and adaptation pathways for culture. In this trial we could not determine statistical differences between treatments. Stored lipids are the main source of energy in crustaceans $[80,81]$ and are usually mobilized via the hemolymph when required for reproduction $[8,10]$. In juveniles, energy demands are evidenced by their growth rates, but energy is also required when stress conditions develop during culture, such as in events of low oxygen concentration. Results show that juveniles exposed to probiotics are probably better prepared for sudden drops in oxygen concentrations as Figure 3 shows higher hemolymph levels of glucose and lactate. Pascual and coworkers [14] reported that total dietary lipids and proteins are usually reflected in hemolymph levels. This would be consistent with this trial, as the mean total glucose and lipid values in the probiotic were, respectively, 36 and $33 \mathrm{mg} /$, as opposed to 4.34 and $5.84 \mathrm{mg} / \mathrm{l}$ for natural productivity. It has been reported that proteins in hemolymph are constituted mainly by hemocyanin $(60-90 \%$ of total shrimp proteins $[35,36]$. An increase in hemocyanin synthesis has been reported under limited oxygen availability, as a mechanism to increase the amount of $\mathrm{O}_{2}$ transport [82-84]. This was not the case for Cheraxquadricarinatus, probably because the exposure time to hypoxic conditions was too short. Indeed, for Litopenaeusvannnamei, the increase in hemocynin levels was observed after 2 weeks of exposure to hypoxia, in contrast to two

(a)

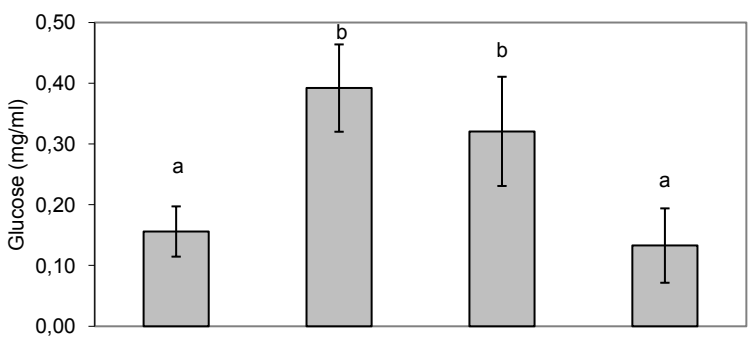

(b)

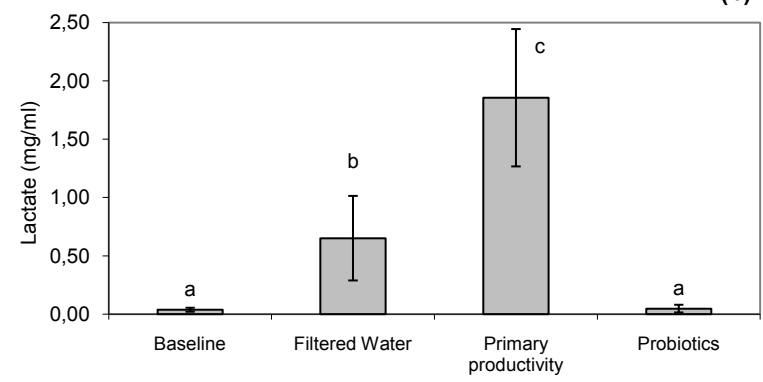

Figure 3: Concentration of glucose (a) and lactate (b) in the hemolymph of juvenile Cherax quadricarinatus for different nutritional substrates after metabolic evaluation. The letters denote significant differences between treatments. (ANOVA P<0.05)

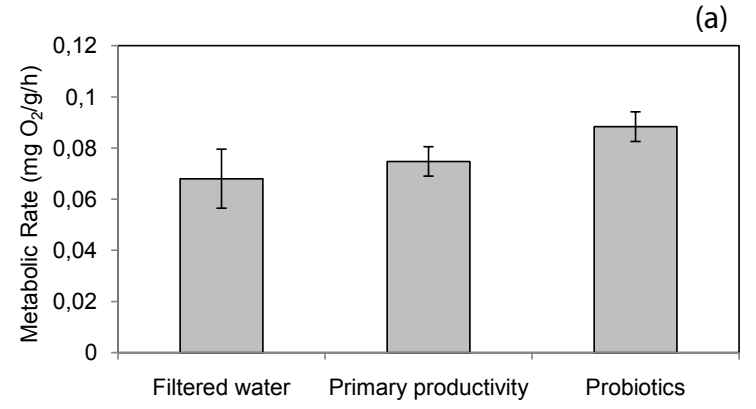

(b)

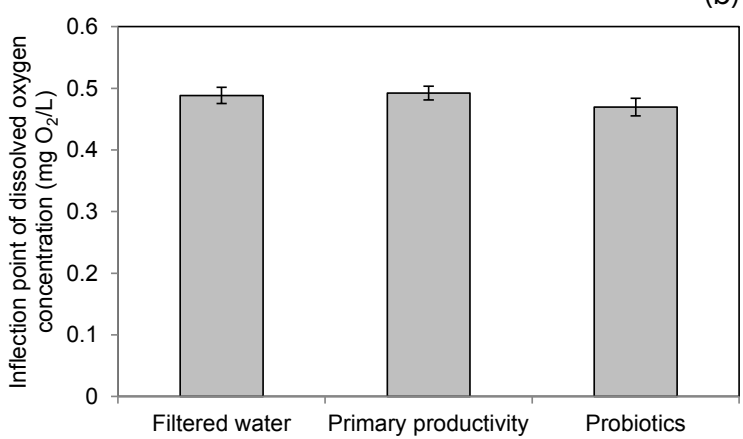

Figure 4: Metabolic rate (a) and the inflection point of dissolved oxygen concentration (IP) (b) of juvenile Cherax quadricarinatus for different treatments: (1) Filtered fresh water, (2) Addition of primary productivity and (3) Addition of probiotics. (ANOVA $\mathrm{P}>0.05$ ).

days-exposure [27]. We obtained a hemocyanine/total protein index of $40 \%$, which is consistent with levels reported for crabs and crayfish $[37,85,86]$, and may represent an adaptive strategy by these organisms where they tolerate lower water oxygen concentrations for some time. This hypothesis is supported by the standard metabolism results and inflection point of dissolved oxygen concentration (IP) levels established in the experiment. Standard metabolic rate for juvenile $C$. quadricarinatus was $0.07 \pm 0.003 \mathrm{mg} . \mathrm{O}_{2} / \mathrm{g} / \mathrm{h}$. This compares favorably with reports for other crustacean species that range from 0.38 to 1.56 $\mathrm{mg} \mathrm{O}_{2} / \mathrm{g} / \mathrm{h}$ [87-90]. In terms of IP, curves for oxygen consumption by C.quadricarinatus showed an inflection point at $0.483 \pm 0.002 \mathrm{mg}$ $\mathrm{O}_{2} / \mathrm{L}$. Reports for shrimp show a limit in the capacity of the organism to control respiration at levels around 2.0-1.3 $\mathrm{mg} \mathrm{O}_{2} / \mathrm{L}$ [91-93]. According to these results Cheraxquadricarinatus is a highly tolerant species to limited oxygen conditions. This is consistent with reports for other species of crayfish, where the organism uses different adaptive strategies allowing them to maintain homeostasis [94], or the use of complex biochemical, physiological or molecular mechanisms of action $[94,95]$ required for crustaceans to survive and tolerate limiting dissolved oxygen conditions. Organisms tolerant to hypoxia frequently control the metabolic rate in both catabolic and anabolic pathways in a coordinated way, reducing total ATP expenditure for extended periods of time [96,97]. This is consistent with low levels of metabolic rate found for C. quadricarinatusin this study (Figure 4).

\section{Acknowledgements}

We thank Roberto Hernandez for his support in biochemical analyses. Julio Felix and Gilberto Gonzalez helped during the trials. Mayra Vargas and Jesus Aguilar maintained the experimental organisms, and Sandra de La Paz and Dr. Teresa Sicard helped in the experimental design. This project is part of the Doctoral 
Citation: Carreño-León D, Racotta-Dimitrov I, Casillas-Hernández R, Monge-Quevedo A, Ocampo-Victoria L, et al. (2014) Growth, Metabolic and Physiological Response of Juvenile Cheraxquadricarinatus Fed Different Available Nutritional Substrates. J Aquac Res Development 5: 220 doi:10.4172/2155-9546.1000220

studies of Diana Carreño, which is funded in part by CONACYT scholarship number 33709, and FINNOVA and CIBNOR projects awarded to Dr. Humberto Villarreal.

\section{References}

1. Lawrence C, Jones C, Holdich DM (2002) Cherax. Biology of Freshwater Crayfish 635-669.

2. Hutchings RW, Villarreal H (1996) Biología Y Cultivo De La Langosta De Agua Dulce Cherax quadricarinatus. Manual De Producción, Navimar, SA Guayaquil, Ecuador.

3. Villarreal H (2000) El Cultivo De La Langosta De Agua Dulce. Una Oportunidad Para La Diversificación Acuícola. Memorias III Simposium Internacional De Acuacultura 5-7.

4. Campaña-Torres A, Martinez-Cordova LR, Villarreal-Colmenares H, CiveraCerecedo R (2005) In Vivo Dry Matter and Protein Digestibility of Three PlantDerived and Four Animal-Derived Feedstuffs and Diets for Juvenile Australian Redclaw, Cherax quadricarinatus. Aquaculture 250: 748-754.

5. Cortés-Jacinto E, Villarreal-Colmenares H, Civera-Cerecedo R, NaranjoPáramo J (2004) Effect of Dietary Protein Level on The Growth and Survival of Pre-Adult Freshwater Crayfish Cherax quadricarinatus (Von Martens) in Monosex Culture. Aquaculture Research 35: 71-79.

6. Campaña-Torres A, Martinez-Cordova LR, Villarreal-Colmenares H, CiveraCerecedo R (2008) Carbohydrate and Lipid Digestibility of Animal and Vegetal Ingredients and Diets for the Pre-Adult Redclaw Crayfish, Cherax Quadricarinatus (Von Martens). Aquaculture Research 39: 1115-1121.

7. García $\square$ Guerrero M (2009) Proximate Biochemical Variations In Eggs of The Prawn Macrobrachium Americanum (Bate, 1869) During Its Embryonic Development. Aquaculture Research 40: 575-581.

8. Serrano-Pinto V, Landais I, Ogliastro MH, Gutiérrez-Ayala M, Mejía-Ruíz H, et al. (2004) Vitellogenin Mrna Expression in Cherax quadricarinatus During Secondary Vitellogenic At First Maturation Females. Molecular Reproduction and Development 69: 17-21.

9. Cahansky AV, Medesani DA, Rodríguez EM (2008) Induction of Ovarian Growth in the Red Claw Crayfish, Cherax Quadricarinatus, By The Enkephalinergic Antagonist Naloxone: In Vivo And In Vitro Studies. Invertebrate Reproduction and Development 51: 61-67.

10. Rodríguez-González H, Villarreal H, García-Ulloa M, Hernández-Llamas A (2009) Evaluation of Practical Diets Containing Different Protein Levels On Gonad Development of Female Redclaw Crayfish Cherax quadricarinatus. Aquaculture Nutrition 15: 347-355.

11. Naranjo-Páramo J, Hernandez-Llamas A, Villarreal H (2004) Effect Of Stocking Density On Growth, Survival And Yield Of Juvenile Redclaw Crayfish Cherax quadricarinatus (Decapoda: Parastacidae) In Gravel-Lined Commercial Nursery Ponds. Aquaculture 242: 197-206.

12. Naranjo J, Villarreal H (2002) Effects Of Aeration Levels On The Growth, Survival and Biomass of Cherax quadricarinatus (Redclaw) Juveniles Reared In Ponds. Book of Abstracts of The Conference Aquaculture America 2002. January 27-30 (World Aquaculture Society). San Diego CA P 230.

13. Martinez-Cordova LR, Porchas-Cornejo MA, Villarreal-Colemnares $\mathrm{H}$ Calderon-Perez JA, Naranjo-Paramo J (1998) Evaluation of Three Feeding Strategies on the Culture of White Shrimp Penaeus vannamei Boone 1931 in Low Water Exchange Ponds. Aquacultural Engineering 17: 21-28.

14. Pascual C, Gaxiola G, Rosas C (2003) Blood Metabolites and Hemocyanin of The White Shrimp, Litopenaeus vannamei: The Effect of Culture Conditions and a Comparison with Other Crustacean Species. Marine Biology 142: 735-745.

15. Günther J, Jiménez-Montealegre R (2004) Efecto Del Probiótico Bacillus subtilis Sobre El Crecimiento Y Alimentación De Tilapia (Oreochromis niloticus) Y Langostino (Macrobrachium rosenbergii) En Laboratorio. Revista De Biología Tropical 52: 937-943.

16. Chaucheyras-Durand F, Durand $H(2010)$ Probiotics in Animal Nutrition and Health. Beneficial Microbes 1: 3-9.

17. Yagi H, Ceccaldi HJ, Gaudy R (1990) Combined Influence of Temperature and Salinity on Oxygen Consumption of the Pink Shrimp, Palaemonserratus (Pennant) (Crustacea, Decapoda, Palaemonidae). Aquaculture 86: 77-92.

18. Meade ME, Watts SA (1995) Toxicity of Ammonia, Nitrite, And Nitrate To Juvenile Australian Crayfish, Cherax quadricarinatus. Journal of Shellfish Research 14: 341-346.
19. Villarreal H (1990) Effect Of Temperature on oxygen Consumption and Heart Rate of The Australian Crayfish Cherax tenuimanus (Smith).Comparative Biochemistry and Physiology Part A: Physiology 95: 189-193.

20. Villarreal H, Ocampo L (1993) Effect of Size and Temperature on the Oxygen Consumption of the Brown Shrimp Penaeus californiensis (Holmes, 1900) Comparative Biochemistry and Physiology Part A: Physiology 106: 97-101.

21. Villarreal H, Rivera J A (1993) Effect of Temperature and Salinity on the Oxygen Consumption of Laboratory Produced Penaeus californiensis Postlarvae. Comparative Biochemistry and Physiology Part A: Physiology 106: 103-107.

22. Villarreal H, Hinojosa P, Naranjo J (1994) Effect of Temperature and Salinity On The Oxygen Consumption of Laboratory Produced Penaeus vanname Postlarvae. Comparative Biochemistry and Physiology Part A: Physiology 108 331-336.

23. Spanopoulos-Hernández M, Martınez-Palacios CA, Vanegas-Pérez RC, Rosas C, Ross LG (2005) The Combined Effects of Salinity and Temperature on The Oxygen Consumption of Juvenile Shrimps Litopenaeus stylirostris (Stimpson, 1874). Aquaculture 244: 341-348.

24. Daoud D, Chabot D, Audet C, Lambert $Y$ (2007) Temperature Induced Variation in Oxygen Consumption of Juvenile and Adult Stage of the Northern Shrimp P.Andalusborealis. Journal of Experimental Marine Biology and Ecology 347: $30-40$

25. Prymaczok NC, Chaulet A, Medesani DA, Rodríguez EM (2012) Survival, Growth, And Physiological Responses Of Advanced Juvenile Freshwater Crayfish (Cherax quadricarinatus), Reared at Low Temperature and High Salinities. Aquaculture 334: 176-181.

26. Ottolenghi C, Puviani AC, Ricci D, Brighenti L, Morsiani E (1995) The Effect Of High Temperature on Blood Glucose Level In Two Teleost Fish Ictalurus melas and Ictalurus punctatus. Comparative Biochemistry and Physiology Part A: Physiology 111: 229-235.

27. Racotta IS, Palacios E, Méndez L (2002) Short Communication: Metabolic Responses to Short and Long-Term Exposure to Hypoxia in White Shrimp (Penaeus vannamei). Marine and Freshwater Behaviour and Physiology 35 269-275.

28. Pascual C, Sánchez A, Sánchez A, Vargas-Albores F, Lemoullac G, et al. (2003) Haemolymph Metabolic Variables and Immune Response In Litopenaeus setiferus Adult Males: The Effect of an Extreme Temperature. Aquaculture 218: 637-650.

29. Adachi K, Wakamatsu K, Ito S, Miyamoto N, Kokubo T, et al. (2005) An Oxygen Transporter Hemocyanin Can Act on The Late Pathway of Melanin Synthesis. Pigment Cell Res 19: 214-219.

30. Prymaczok NC, Medesani DA, Rodríguez EM (2008) Levels Of lons And Organic Metabolites In The Adult Freshwater Crayfish, Cherax quadricarinatus, Exposed To Different Salinities. Marine and Freshwater Behaviour And Physiology 41: 121-130.

31. Palacios E, Perez-Rostro Cl, Ramirez JL, Ibarra AM, Racotta IS (1999) Reproductive Exhaustion In Shrimp (Penaeus vannamei) Reflected in Larval Biochemical Composition, Survival and Growth. Aquaculture 171: 309-321.

32. Pérez-Jar L, Rodríguez-Ramos T, Ramos L, Guerra-Borrego Y, Racotta IS (2006) Changes in Metabolic and Immunological Variables of Wild and PondReared Southern White Shrimp Litopenaeus schmitti Adult Males During Continuous Reproductive Activity. Aquaculture 252: 591-597.

33. Guerrero M, Villarreal H, Racotta IS (2003) Effect of Temperature on Lipids, Proteins, and Carbohydrates Levels During Development From Egg Extrusion To Juvenile Stage of Cherax quadricarinatus (Decapoda: Parastacidae). Comparative Biochemistry and Physiology-Part A: Molecular \& Integrative Physiology 135: 147-154

34. Pascual C, Arena L, Cuzon G, Gaxiola G, Taboada G, et al. (2004) Effect of a Size-Based Selection Program on Blood Metabolites and Immune Response of Litopenaeus vannamei Juveniles Fed Different Dietary Carbohydrate Levels. Aquaculture 230: 405-416.

35. Rosas C, Cooper EL, Pascual C, Brito R, Gelabert R, et al. (2004) Indicators of Physiological and Immunological Status of Litopenaeus setiferus Wild Population (Crustacea, Penaeidae). Marine Biology 145: 401- 413.

36. Pascual C, Sánchez A, Zenteno E, Cuzon G, Gaxiola G, et al. (2006) Biochemical, Physiological, and Immunological Changes During Starvation In Juveniles of Litopenaeus vannamei. Aquaculture 251:416-429. 
Citation: Carreño-León D, Racotta-Dimitrov I, Casillas-Hernández R, Monge-Quevedo A, Ocampo-Victoria L, et al. (2014) Growth, Metabolic and Physiological Response of Juvenile Cheraxquadricarinatus Fed Different Available Nutritional Substrates. J Aquac Res Development 5: 220 doi:10.4172/2155-9546.1000220

Page 6 of 7

37. Paschke K, Cumillaf JP, Loyola S, Gebauer P, Urbina M, et al. (2010) Effect of Dissolved Oxygen Level on Respiratory Metabolism, Nutritional Physiology, and Immune Condition Of Southern King Crab Lithodes santolla (Molina, 1782) (Decapoda, Lithodidae). Marine Biology 157: 7-18.

38. Rodríguez-González H, Villarreal H, Hernández-Llamas A, García-Ulloa $M$, Vázquez-Boucard C, et al. (2011) Effect Of Dietary Protein To Energy Ratio on Reproduction In Female Redclaw Crayfish Cherax quadricarinatus. Aquaculture Research 42: 1840-1847.

39. Racotta IS, Palacios E (1998) Hemolymph Metabolic Variables in Response to Experimental Manipulation Stress and Serotonin Injection in Penaeus vannamei. Journal of the World Aquaculture Society 29: 351-356.

40. Aparicio-Simón B, Piñón M, Radu R, Racotta IS (2010) Neuroendocrine and Metabolic Responses of Pacific White Leg Shrimp Litopenaeus vannamei Exposed To Acute Handling Stress. Aquaculture 298: 308-314.

41. Hsieh SH, Ruan YH, Li YC, Hsieh PS, Hu CH, Et Al. (2008) Immune And Physiological Responses In Pacific White Shrimp (Penaeus vannamei) To Vibrio Alginolyticus. Aquaculture 275: 335-341.

42. King C (1994) Growth and Survival of Redclaw Crayfish Hatchlings (Cherax quadricarinatus Von Martens) In Relation To Temperature, With Comments on the Relative Suitability of Cherax quadricarinatus and Cherax destructor for Culture in Queensland. Aquaculture 122: 75.

43. Villarreal H, Peláez J (1999) Biología Y Cultivo De Langosta De Agua Dulce Cherax Quadricarinatus. Centro De Investigaciones Biológicas Del Noroeste and Acuacultivos Santo Domingo. La Paz. Baja California Sur, México.

44. Meade ME, Doeller JE, Kraus D, Watts SA (2002) Effects of Temperature and Salinity on Weight Gain, Oxygen Consumption Rate, and Growth Efficiency in Juvenile Red-Claw Crayfish Cherax quadricarinatus. Journal of The World Aquaculture Society 33: 188-198.

45. Jones CM, Ruscoe IM (2000) Assessment of Stocking Size and Density in The Production of Redclaw Crayfish, Cherax quadricarinatus (Von Martens) (Decapoda: Parastacidae), Cultured Under Earthen Pond Conditions. Aquaculture 189: 63-71.

46. Verschuere L, Rombaut G, Sorgeloos P, Verstraete W (2000) Probiotic Bacteria as Biological Control Agents in Aquaculture. Microbiology and Molecular Biology Reviews 64: 655-671.

47. Yu MC, Li ZJ, Lin HZ, Wen GL, Ma S (2008) Effects of Dietary Bacillus and Medicinal Herbs on The Growth, Digestive Enzyme Activity, and Serum Biochemical Parameters of The Shrimp Litopenaeus vannamei. Aquaculture International 16: 471-480

48. Avnimelech Y (2006) Bio-Filters: The Need for an New Comprehensive Approach. Aquacultural Engineering 34: 172-178.

49. Campaña-Torres A, Martínez-Córdova LR, Villarreal-Colmenares $H$ Hernández-López J, Ezquerra-Brauer JM, et al. (2009) Efecto De La Adición Del Rotífero Brachionus rotundiformis (Tschugunoff, 1921) Sobre La Calidad Del Agua Y La Producción, En Cultivos Super-Intensivos De Camarón Blanco Del Pacífico Litopenaeus vannamei (Boone, 1931). Revista De Biología Marina Y Oceanografía 44: 335-342

50. Vinatea L, Galvez AO, Browdy CL, Stokes A, Venero J, et al. (2010) Photosynthesis, Water Respiration and Growth Performance of Litopenaeus vannamei in a Super-Intensive Raceway Culture with Zero Water Exchange: Interaction of Water Quality Variables. Aquacultural Engineering 42: 17-24.

51. Gatesoupe FJ (1999) The Use of Probiotics in Aquaculture. Aquaculture 180: 147-165.

52. Green DH, Wakeley PR, Page A, Barnes A, Baccigalupi L, et al. (1999) Characterization of Two Bacillus Probiotics. Applied and Environmental Microbiology 65: 4288-4291.

53. Rengpipat S, Rukpratanporn S, Piyatiratitivorakul S, Menasaveta P (2000) Immunity Enhancement in Black Tiger Shrimp (Penaeus monodon) by a Probiont Bacterium (Bacillus S11). Aquaculture 191: 271-288.

54. Lara-Flores M, Olvera-Novoaa MA, Guzmán-Méndez BE, López-Madrid W (2003) Use of The Bacteria Streptococcus faecium and Lactobacillus acidophilus, and The Yeast Saccharomyces cerevisiae as Growth Promoters in Nile Tilapia (Oreochromis niloticus). Aquaculture 216: 193-201.

55. Carnevali O, Zamponi MC, Sulpizio R, Rollo A, Nardi M, et al. (2004) Administration of Probiotic Strain to Improve Sea Bream Wellness During Development. Int Aquacul 12: 377-386.
56. Vázquez JA, González M, Murado MA (2005) Effects of Lactic Acid Bacteria Cultures on Pathogenic Microbiota from Fish. Aquaculture 245: 149-161.

57. Rengpipat S, Phianphak W, Piyatiratitivorakul S, Menasveta P (1998) Effects of a Probiotic Bacterium on Black Tiger Shrimp Penaeus monodon Survival and Growth. Aquaculture 167: 301-313.

58. Rengpipat S, Tunyanun A, Fast AW, Piyatiratitivorakul S, Menasveta P (2003) Enhanced Growth and Resistance To Vibrio Challenge in Pond-Reared Black Tiger Shrimp Penaeus monodon Fed a Bacillus Probiotic. Diseases of Aquatic Organisms 55: 169-173.

59. Gómez RGD, Shen MA (2008) Influence of Probiotics on the Growth and Digestive Enzyme Activity of White Pacific Shrimp (Litopenaeus vannamei) Journal of Ocean University of China 7: 215-218.

60. EL-Haroun ER, Goda AS, Chowdhury K (2006) Effect of Dietary Probiotic Biogen $\circledast$ Supplementation as a Growth Promoter On Growth Performance And Feed Utilization of Nile Tilapia Oreochromis niloticus (L.). Aquaculture Research 37: 1473-1480.

61. Wang YB, Li JR, Lin J (2008) Probiotics in Aquaculture: Challenges and Outlook. Aquaculture 281: 1-4.

62. Kennedy SB, Tucker JW J, Thomersen M, Sennett, DG (1998) Current Methodology for The Use Of Probiotic Bacteria In The Culture Of Marine Fish Larvae. In Aquaculture'98 Book of Abstracts 286: 193-201.

63. Douillet PA, Langdon CJ (1994) Use of a Probiotic for the Culture of Larvae of the Pacific Oyster (Crassostrea gigas Thunberg). Aquaculture 119: 25-40.

64. Moriarty DJW (1999) Disease Control In Shrimp Aquaculture With Probiotic Bacteria. Proceedings Of The 8th International Symposium On Microbia Ecology 237-243.

65. Irianto A, Austin B (2002) Probiotics In Aquaculture. Journal of Fish Diseases 25: 633-642.

66. Farzanfar A (2006) The Use Of Probiotics In Shrimp Aquaculture. FEMS Immunology \& Medical Microbiology 48: 149-158.

67. Cortés-Jacinto E, Villarreal-Colmenares $H$, Civera-Cerecedo $\mathrm{R}$, MartínezCórdova R (2003) Effect Of Dietary Protein Level On Growth and Survival of Juvenile Freshwater Crayfish Cherax quadricarinatus (Decapoda: Parastacidae). Aquaculture Nutrition 9: 207-213.

68. Chen JC, Cheng SY (1994) Studies On Haemocyanin And Haemolymph Protein Levels of Penaeus japonicus Based on Sex, Size and Moulting Cycle. Comparative Biochemestry and Physiology 106B: 293-296.

69. Carreño D (2000) Alteraciones Metabólicas Del Camarón Blanco Litopenaeus vannamei En Respuesta A La Manipulación Rutinaria Bajo Condiciones De Cultivo Y A La Ablación Del Tallo Ocular. Tesis De Maestría Del Centro Interdisciplinario De Ciencias Del Mar. La Paz, Baja California Sur. México.

70. Bradford MM (1976) A Rapid and Sensitive Method for The Quantitation of Microgram Quantities of Protein Utilizing The Principle of Protein-Dye Binding. Analytical Biochemistry 72: 248-254.

71. Barnes H, Blackstock J (1973) Estimation of Lipids In Marine Animals and Tissues: Detailed Investigation of The Sulphophosphovanilun Method for 'Total'lipids. Journal of Experimental Marine Biology and E Ology 12: 103-118.

72. Scelzo MA, Zuñiga O (1987) Consumo De Oxígeno En El Camarón Penaeus Brasiliensis Latreille (Decapoda: Penaeidae) En Relación A Salinidad Y Temperatura. Memorias De La Sociedad De Ciencias Naturales De La Universidad La Salle 127-128.

73. Ocampo L, Villarreal H, Vargas M, Portillo G, Magallón F (2000) Effect of Dissolved Oxygen and Temperature on Growth, Survival and Body Composition of Juvenile Farfantepenaeus californiensis (Holmes). Aquaculture Research 31: 167-171.

74. Sokal RR, Rohlf FJ (1995) The Principles And Practice Of Statistics In Biological Research. New York: Edition 3.

75. Zar JH (1999) Biostatiscal Analysis. Prentice Hall, Upper Saddle River, N.J, 663.

76. Thompson KR, Muzinic LA, Engler LS, Morton SR, Webster CD (2004) Effects Of Feeding Practical Diets Containing Various Protein Levels On Growth Survival, Body Composition, And Processing Traits Of Australian Red Claw Crayfish (Cherax quadricarinatus) And On Pond Water Quality. Aquaculture Research 35: 659-668. 
Citation: Carreño-León D, Racotta-Dimitrov I, Casillas-Hernández R, Monge-Quevedo A, Ocampo-Victoria L, et al. (2014) Growth, Metabolic and Physiological Response of Juvenile Cheraxquadricarinatus Fed Different Available Nutritional Substrates. J Aquac Res Development 5: 220 doi:10.4172/2155-9546.1000220

77. Cortés-Jacinto E, Villarreal-Colmenares H, Cruz-Suárez LE, Civera-Cerecedo R, Nolasco-Soria H, Et Al. (2005) Effect Of Different Dietary Protein And Lipid Levels On Growth And Survival Of Juvenile Australian Redclaw Crayfish, Cherax quadricarinatus (Von Martens). Aquaculture Nutrition 11: 283-291.

78. D'Abramo LR, Robinson EH (1989) Nutrition Of Crayfish. Rev Aquat Sci 1 711-728.

79. Lopez-Lopez S, Nolasco H, Villarreal-Colmenares H, Civera-Cerecedo R (2005) Digestive Enzyme Response To Supplemental Ingredients In Practical Diets For Juvenile Freshwater Crayfish Cherax quadricarinatus. Aquaculture Nutrition 11: 79-85

80. Mourente G, Medina A, Gonzalez S, Rodriguez A (1994) Changes In Lipid Class And Fatty Acid Contents in The Ovary And Midgut Gland Of The Female Fiddler Crab Uca Tangeri (Decapoda, Ocypodiadae) During Maturation. Marine Biology 121: 187-197.

81. Luvizotto-Santos R, Lee J, Branco Z, Bianchini A, Nery L (2003) Lipids As Energy Source During Salinity Acclimation In The Euryhaline Crab Chasmagnathus granulata Dana, 1851 (Crustacea-Grapsidae). Journal Of Experimental Zoology 295: 200

82. Baden PS, Depledge MH, Hagerman L (1994) Glycogen Depletion And Altered Copper And Manganese Handling In Nephrops norvegicus Following Starvation And Exposure To Hypoxia. Marine Ecology Progress Series 103: 65-72.

83. Scholnick DA, Snyder GK (1996) Response of The Tadpole Shrimp Triops longicaudatus To Hypoxia. Crustaceana 69: 937-948.

84. Mangum CP (1997) Adaptation of the Oxygen Transport System to Hypoxia in the Blue Crab, Callinectes sapidus. American Zoologist 37: 604-611.

85. Hagerman L, Uglow RF (1985) Effects Of Hypoxia On The Respiratory and Circulatory Regulation of Nephrops norvegicus. Marine Biology 87: 273-278.

86. Spicer JI, Baden SP (2000) Natural Variation In The Concentrations of Haemocyanin From Three Decapod Crustaceans, Nephrops norvegicus, Liocarcinus depurator and Hyas aranaeus. Marine Biology 136: 55-61.

87. Wickins JF (1976) The Tolerance of Warm-Water Prawns to Recirculated Water. Aquaculture 9: 19-37.
88. Paterson BD, Thorne MJ (1995) Measurements of Oxygen Uptake, Heart and Gill Bailer Rates of The Callianassid Burrowing Shrimp Trypaea australiensis Dana and Its Responses To Low Oxygen Tensions. Journal of Experimental Marinebiology And Ecology 194: 39-52.

89. Rosas C, Sanchez A, Gaxiola G, Brito R, Baes M, Et Al. (1995) Oxygen Consumption And Ammonia Excretion Of Penaeus setiferus, $P$. schmitti, $P$. duorarum and $P$. notialis Postlawae Fed Purified Test Diets: Effect of Protein Level On Substrate Metabolism. Aquatic Living Resources 8: 161-169.

90. Villarreal H, Hernández-Llamas A, Hewitt R (2003) Effect of Salinity on Growth Survival and Oxygen Consumption of Juvenile Brown Shrimp Farfantepenaeus californiensis (Holmes). Aquaculture Research 34: 187-193.

91. Seidman ER, Lawrence AL (1985) Growth. Feed Digestibility, and Proximate Body Composition of Juvenile Penaeus vannamei and Penaeus monodon Grown at Different Dissolved Oxygen Levels. Journal of the World Mariculture Society 16: 333-346.

92. Villarreal H (1989) Feeding, Growth and Energetics of The Freshwater Crayfish Cherax tenuimanus (Smith) With Special Emphasis on Its Potentia for Commercial Culture. Ph.D. Thesis, Department Of Zoology. University Of Queensland. Australia, $249 \mathrm{P}$.

93. Ocampo L (2001) Critical Oxygen Point in Yellow Leg Shrimp, Farfantepenaeus californensis A Potential Species For The Live Trade. Marketing and Shipping Live Aquatic Products Paust, BC Rice, AA (Eds). University Of Alaska Sea Grand 23-26.

94. Gorr TA, Wichmann D, Hu J, Hermes-Lima M, Welker AF, et al. (2010) Hypoxia Tolerance in Animals: Biology and Application. Physiological and Biochemical Zoology 83: 733-752

95. Mcmahon BR (2001) Respiratory and Circulatory Compensation to Hypoxia in Crustaceans. Respiration Physiology 128: 349-364.

96. Storey KB, Storey JM (1990) Metabolic Rate Depression and Biochemica Adaptation in Anaerobiosis, Hibernation and Estivation. Quarterly Review of Biology 65: 145-174.

97. Storey KB, Storey JM (2007) Tribute to PL Lutz: Putting Life Onpause'Molecular Regulation of Hypometabolism. Journal of Experimental Biology 210: $1700-1714$ 